\title{
Apportionment of Hazardous Elements in Agricultural Soils Around the Vicinity of Brick Kiln in Bangladesh
}

\section{Ram Proshad*, Saad Ahmed, Mahfuzur Rahman and Tapan Kumar}

Department of Soil Science, Patuakhali Science and Technology University, Dumki, Patuakhali-8602, Bangladesh

\begin{abstract}
Natural and anthropogenic factors affect soil pollution which significantly reduces environmental quality. In this study, six hazardous elements namely Chromium (Cr), Nickel (Ni), Arsenic (As), Cadmium (Cd) and Lead ( $\mathrm{Pb}$ ), in 12 different sampling sites around brick kiln vicinity from Bangladesh were assessed. The ranges of $\mathrm{Cr}, \mathrm{Ni}, \mathrm{Cu}, \mathrm{As}, \mathrm{Cd}$ and $\mathrm{Pb}$ in studied soils were $0.77-21.71,4.74-27.67,3.08-38.56,2.51-28.44,1.03-8.06$ and 2.23-18.31 mg/kg, respectively. Presence of these hazardous elements in soils is indicating a potential risk to the environment. Certain indices, including the enrichment factor (EF), pollution load index (PLI) and contamination factor $\left(\mathrm{C}_{\mathrm{f}}^{\mathrm{i}}\right)$, geoaccumulation index $\left(\mathrm{I}_{\text {geo }}\right)$, toxic unit analysis and principal component analysis (PCA) were used to assess the ecological risk posed by hazardous elements in soils. The $\mathrm{C}_{f}^{i}$ values of $\mathrm{As}$ (15.34) and $\mathrm{Cd}(37.89)$ revealed that the examined soils were strongly impacted by As and Cd where Pollution load index in As (1.01) and Cd (2.61) indicating progressive deterioration of soil due to metal contamination. In view of the above results, soils from all sampling sites showed considerable to very high potential ecological risk.
\end{abstract}

Keywords: Heavy metals; Arsenic; Cadmium; Soil; Brick kiln; Enrichment factors; Pollution load index

\section{Introduction}

Brick kiln have adverse effect to soils which causes soil pollution. Soil is an in born resource for the survival of living being which concerned as the explanation receiver of the merciless pollutants like hazardous elements [1]. Hazardous elements are of great concern due to their wide sources, toxicity, non-biodegradable properties and accumulative behaviors [2]. Trace metals such as Chromium (Cr), Nickel (Ni), Arsenic (As), Cadmium $(\mathrm{Cd})$ and Lead $(\mathrm{Pb})$ have been considered as the most toxic elements in the environment by the US Environment Protection Agency (EPA) [1,3]. Brick production in brick kiln is traditional and fast growing industry in many parts of Asia like Bangladesh. Due to industrialization, use of bricks are increasing day by day as attractive building materials and for this an ample amount of brick kiln industries are set up here and there in Bangladesh. For very speedy urbanization, to meet the requirement of brick in construction industry there produce about 8.6 billion bricks per year. The annual rate of demand for the bricks rising is about $5.28 \%$ and which is rapidly increasing every year [4]. Hazardous elements may originate in soils around brick kiln area from different sources of which are industrial activities, fuel and coal combustion, wood burning, tyres and furnace oil in the brick kiln [5]. From brick kilns, ambient hazardous elements are being brought forward every year which are mixed up with air causes air pollution and rest are being stored in soils and create soil toxicity [6]. Therefore, the accumulation of hazardous elements in soils is of increasing concern due to their potential risk, and detrimental effects on soil ecosystems $[7,8]$. In brick kiln area, there should be concern about the soil pollution and ecological risks because the rate of emission of toxic substance is very high in developing countries, especially in Bangladesh as the rules and regulations are being broken which should be maintained for brick kiln. Different methods are usually used to determine hazardous elements contamination in soil like contamination factor $\left(\mathrm{C}_{\mathrm{f}}^{\mathrm{i}}\right)$, enrichment factor (EF), geoaccumulation index $\left(\mathrm{I}_{\text {geo }}\right)$, pollution load index (PLI) etc. [9]. The EF of an area indicates the relative enrichment in any contaminant when compared to pre-industrial soils from the same environment $[10,11]$. As soil pollution arising from brick kiln, the study area have raised attention due to its environmental pollution which is facing serious threats due to elemental pollution originated from the rapid expansion, congestion, and activities from brick kilns [12]. Several studies have reported the concentration of hazardous elements in agricultural soils due to brick kiln in Bangladesh [13-15]. The main aim to present research are to address the problem of hazardous elements like $\mathrm{Cr}, \mathrm{Ni}, \mathrm{Cu}, \mathrm{As}, \mathrm{Cd}$, and $\mathrm{Pb}$ around brick kiln area soils and to find out the ecological risk of such hazardous elements in soils around brick kiln area in Bangladesh.

\section{Materials and Methods}

\section{Study area and sampling}

Twelve different sampling sites were selected for this study in Tangail district, Bangladesh (Figure 1). The area of Tangail district is $3414.28 \mathrm{~km} 2$ and located at the center point in Bangladesh. Tangail district is one of the most densely polluted areas in Bangladesh where the density of population is $1.100 / \mathrm{km}^{2}$ (2011 census). The study area is situated between $24^{\circ} 01^{\prime}$ and $24^{\circ} 47^{\prime}$ north latitudes and between $89^{\circ} 44^{\prime}$ and $90^{\circ} 18^{\prime}$ east longitudes (Wikipedia). During March- April, 2016 soil samples were collected. Twelve sampling sites were selected around the brick kiln area. In every sampling site, agricultural soil samples (surface soils) were accumulated in the form of three subsamples. To make a composite sample, three subsamples were mixed together. Samples were kept in cool place and dried in air at room temperature for two weeks, then these were ground and homogenized for determination of hazardous elements. A porcelain mortar and pestle was used to crumble the soils and $2 \mathrm{~mm}$ nylon sieve was used to sieve the soils and stored in an airtight clean Ziploc bag and kept frozen until chemical analysis.

*Corresponding author: Ram Proshad, Department of Soil Science, Patuakhali Science and Technology University, Dumki, Patuakhali-8602, Bangladesh, E-mail: saad.pstums@gmail.com

Received February 13, 2017; Accepted February 22, 2017; Published February 27, 2017

Citation: Proshad R, Ahmed S, Rahman M, Kumar T (2017) Apportionment of Hazardous Elements in Agricultural Soils Around the Vicinity of Brick Kiln in Bangladesh. J Environ Anal Toxicol 7: 439. doi: 10.4172/2161-0525.1000439

Copyright: (c) 2017 Proshad R, et al. This is an open-access article distributed under the terms of the Creative Commons Attribution License, which permits unrestricted use, distribution, and reproduction in any medium, provided the original author and source are credited. 
Citation: Proshad R, Ahmed S, Rahman M, Kumar T (2017) Apportionment of Hazardous Elements in Agricultural Soils Around the Vicinity of Brick Kiln in Bangladesh. J Environ Anal Toxicol 7: 439. doi: 10.4172/2161-0525.1000439

Page 2 of 6

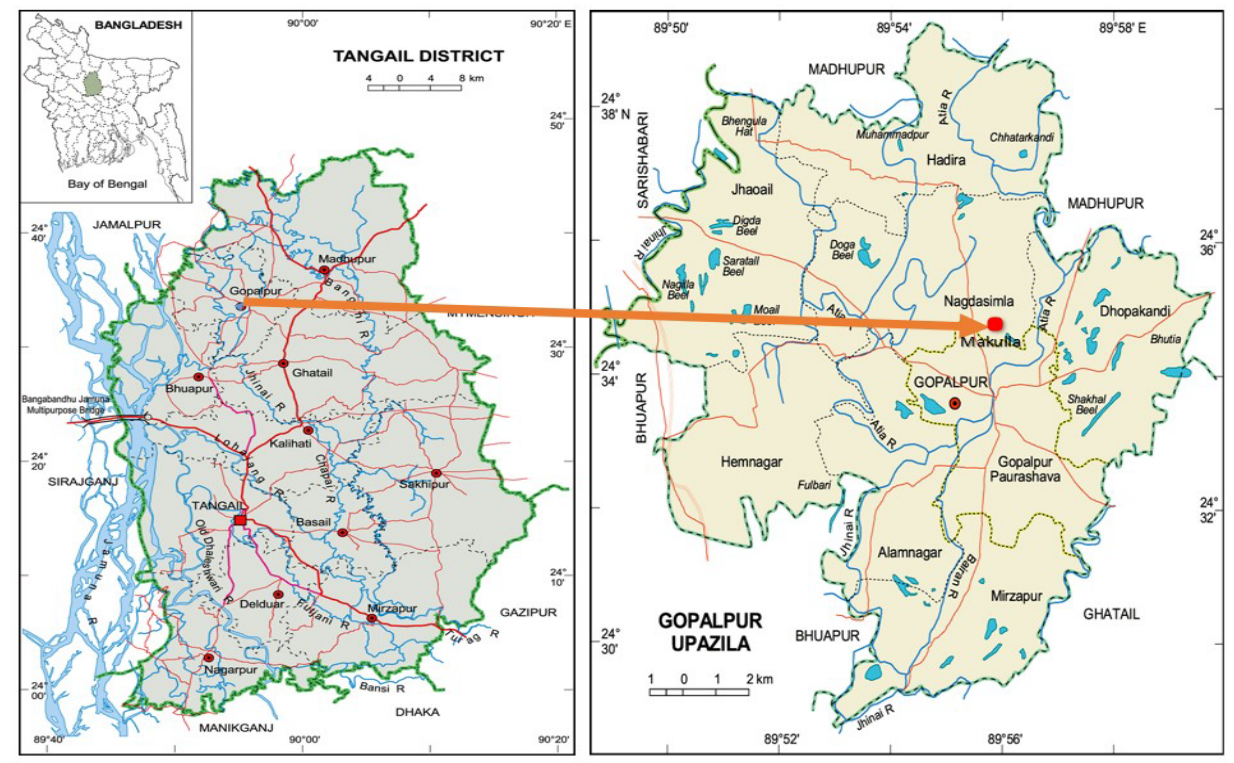

Figure 1: Map of the sampling sites in Tangail district, Bangladesh.

\section{Sample analysis}

For sample analysis, analytical grade reagents were used and for solution preparation Milli-Q (Elix UV5 and MilliQ, Millipore, USA) water was used. $0.3 \mathrm{~g}$ of the soil sample was mixed with $1.5 \mathrm{~mL} 69 \%$ $\mathrm{HNO}_{3}$ (Kanto Chemical Co, Tokyo, Japan) and $4.5 \mathrm{~mL} 35 \% \mathrm{HCl}$ (Kanto Chemical Co, Tokyo, Japan) in a closed Teflon vessel and was digested in a Microwave Digestion System (Berghof speedwave, Eningen, Germany) for metal analysis. By using a syringe filter (DISMIC $-25 \mathrm{HP}$ PTFE, pore size $=0.45 \mu \mathrm{m}$ ) [11] Toyo Roshi Kaisha, Ltd., Tokyo, Japan the solution was digested and $50 \mathrm{~mL}$ polypropylene tubes (Nalgene, New York) were used for storing.

\section{Quality control and instrumental analysis}

Inductively coupled plasma mass spectrometer (ICP-MS, 7700 series) was used for sample analysis. To prepare calibration curve, Multi-element Standard XSTC-13 (SpexCertiPrep;, Metuchen, USA) solutions were used. Due to cover more range of masses of elements, 1.0 $\mu \mathrm{g} / \mathrm{L}$ multi-element solution was used as tuning solution. An internal quality system was used for evaluation every test batches. Once defined Internal Quality Controls (IQCs) was satisfied than it was validated.

\section{Ecological risk assessment for soil pollution}

Contamination factor $\left(\mathrm{C}_{\mathrm{f}}^{\mathrm{i}}\right)$ : The $\left(\mathrm{C}_{\mathrm{f}}^{\mathrm{i}}\right)$ may be defined as the ratio of the metal concentration in the soil to that of baseline or background value (background value is considered as toxic elements in the preindustrial soil around research vicinity)

$$
\mathrm{C}_{\mathrm{f}}^{\mathrm{i}}=\mathrm{C}_{\text {heavy metal }} / \mathrm{C}_{\text {background }}
$$

According to the intensities of contamination, the levels of contamination may be divided on six categories which range from 1 to 6: very high degree $\left(\mathrm{C}_{\mathrm{f}}^{\mathrm{i}} \geq 6\right)$, considerable degree $\left(3 \leq \mathrm{C}_{\mathrm{f}}^{\mathrm{i}}<6\right)$, moderate degree $\left(1 \leq C_{f}^{i}<3\right)$ and low degree $\left(C_{f}^{i}<1\right)[16,17]$. Thus, the enrichment of each metal may be monitored by $\mathrm{C}_{\mathrm{f}}^{\mathrm{i}}$ values over a long time in soils.

\section{Enrichment factor (EF)}

For assessing the magnitude of hazardous elements in the environment, enrichment factor is assumed impressive tool [18]. For determination anthropogenic influences of hazardous elements in soil, enrichment factor was calculated using the following formula [19].

$$
\left.\mathrm{EF}=\left(\mathrm{C}_{\mathrm{M}} / \mathrm{C}_{\mathrm{Al}}\right)_{\text {sample }} /\left(\mathrm{C}_{\mathrm{M}} / \mathrm{C}_{\mathrm{Al}}\right)\right)_{\text {background }}
$$

Where, $\left(\mathrm{C}_{\mathrm{M}} / \mathrm{C}_{\mathrm{Al}}\right)_{\text {sample }}$ is assumed as ratio of hazardous element concentration of $\left(\mathrm{C}_{\mathrm{M}}\right)$ to that of aluminum $\left(\mathrm{C}_{\mathrm{Al}}\right)$ in the soil sample, and $\left.\left(\mathrm{C}_{\mathrm{M}} / \mathrm{C}_{\mathrm{Al}}\right)\right)_{\text {background }}$ is the same reference ratio in the background sample. If the $\mathrm{EF}$ value of heavy metals is 1 , it means that metal may be entirely from crustal materials or natural weathering processes [20]. It is stating a fact of human interference if enrichment factor of samples is more than 1.5. An EF of 1.5-3, 3-5, 5-10 and $>10$ is considered the evidence of minor, moderate, severe, and very severe modification [21].

\section{Geoaccumulation index $\left(\mathrm{I}_{\text {geo }}\right)$}

$\mathrm{I}_{\text {geo }}$ may be considered as an effective tool for assessing degree of contamination from hazardous element. It use universally for determination of soil concentration now a days [22]. One of the most important purposes for assessing $I_{\text {geo }}$ is to characterize the level of pollution from soil. $\mathrm{I}_{\text {geo }}$ can be determined adopting following equation

$$
\mathrm{I}_{\text {geo }}=\log _{2}\left(\mathrm{C}_{\mathrm{n}} / 1.5 \mathrm{~B}_{\mathrm{n}}\right)
$$

Where, $C_{n}$ is the assessed metal ( $n$ ) concentration in the soil and $B_{n}$ is considered as the geochemical baseline value of metal $\mathrm{n}$ in the baseline sample [23-25]. For reducing the probable variations in the baseline values of metal $\mathrm{n}$, factor 1.5 is used that can be ascribed to lithogenic effects. $\mathrm{I}_{\text {geo }}$ values were categorized as: $5<\mathrm{I}_{\text {geo }}$ - extremely contaminated; $4 \leq \mathrm{I}_{\text {geo }} \leq 5$-heavily to extremely contaminated; $3 \leq \mathrm{I}_{\text {geo }} \leq 4$-heavily contaminated; $2 \leq \mathrm{I}_{\text {geo }} \leq 3$ - moderately to heavily contaminated; $1 \leq$ $\mathrm{I}_{\text {geo }} \leq 2$-moderately contaminated; $0 \leq \mathrm{I}_{\text {geo }} \leq 1$-uncontaminated to moderately contaminated; and $\mathrm{I}_{\text {geo }} \leq 0$-practically uncontaminated.

\section{Pollution load index (PLI)}

Pollution load index act as an integrated approach which assess soil quality. of the six metals is calculated according to Suresh et al. [26] pollution load index may be assessed from six hazardous elements $(\mathrm{Cr}, \mathrm{Ni}$, $\mathrm{Cu}, \mathrm{As}, \mathrm{Cd}$ and $\mathrm{Pb}$ ). The PLI can be calculated by using following formula 
Citation: Proshad R, Ahmed S, Rahman M, Kumar T (2017) Apportionment of Hazardous Elements in Agricultural Soils Around the Vicinity of Brick Kiln in Bangladesh. J Environ Anal Toxicol 7: 439. doi: 10.4172/2161-0525.1000439

Page 3 of 6

\begin{tabular}{|c|c|c|c|c|c|c|c|}
\hline Sampling sites & $\mathrm{pH}(1: 2.5 \mathrm{H} 2 \mathrm{O})$ & $E C(d S / m)$ & Organic carbon (\%) & Sand $(\%$ in <2 mm) & Silt & Clay & Soil type ${ }^{a}$ \\
\hline $\mathrm{S} 1$ & 6.54 & 0.43 & 3.566 & 35.1 & 46.6 & 18.3 & Loam \\
\hline S2 & 6.78 & 0.13 & 1.343 & 41 & 45 & 14 & Loam \\
\hline S3 & 6.95 & 0.1 & 3.607 & 55 & 30 & 15 & Sandy loam \\
\hline S4 & 6.44 & 0.08 & 1.335 & 39.7 & 45 & 15.3 & Loam \\
\hline S5 & 6.02 & 0.07 & 3.650 & 35 & 51 & 14 & Silt loam \\
\hline S6 & 6.25 & 0.18 & 1.352 & 44 & 37.5 & 18.5 & Loam \\
\hline S7 & 6.05 & 0.06 & 0.553 & 34 & 47.5 & 18.5 & Loam \\
\hline S8 & 6.93 & 0.17 & 0.551 & 34.7 & 45 & 20.3 & Loam \\
\hline S9 & 6.83 & 0.15 & 0.552 & 34.9 & 47.5 & 17.6 & Loam \\
\hline $\mathrm{S} 10$ & 6.45 & 0.12 & 2.547 & 48.5 & 39.1 & 12.4 & Loam \\
\hline $\mathrm{S} 11$ & 7.87 & 0.47 & 0.545 & 44.7 & 37.5 & 17.8 & Loam \\
\hline $\mathrm{S} 12$ & 6.81 & 0.1 & 0.537 & 36.5 & 45 & 18.5 & Loam \\
\hline
\end{tabular}

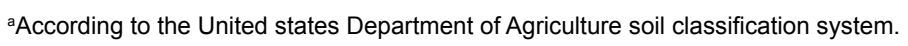

Table 1: Physiochemical properties of soil from Tangail district brick manufacturing area, Bangladesh.

\begin{tabular}{|c|c|c|c|c|c|c|}
\hline Sampling sites & $\mathrm{Cr}$ & $\mathrm{Ni}$ & $\mathrm{Cu}$ & As & Cd & $\mathrm{Pb}$ \\
\hline $\mathrm{S} 1$ & 11.23 & 4.74 & 10.75 & 4.67 & 1.18 & 5.99 \\
\hline $\mathrm{S} 2$ & 10.12 & 11.39 & 9.66 & 11.12 & 7.2 & 6.24 \\
\hline S3 & 21.71 & 12.21 & 29.56 & 7.61 & 2.01 & 10.99 \\
\hline S4 & 11.93 & 9.75 & 14.08 & 14.94 & 2.01 & 3.98 \\
\hline S5 & 17.25 & 5.34 & 6.0 & 19.07 & 2.49 & 3.24 \\
\hline S6 & 0.77 & 25.71 & 3.08 & 2.69 & 2.76 & 2.23 \\
\hline S7 & 10.86 & 9.11 & 8.26 & 28.44 & 8.06 & 17.93 \\
\hline S8 & 9.41 & 27.67 & 6.93 & 2.51 & 1.03 & 8.62 \\
\hline S9 & 8.21 & 18.77 & 26.93 & 13.36 & 2.82 & 18.32 \\
\hline S10 & 1.57 & 12.40 & 29.30 & 7.51 & 2.01 & 10.96 \\
\hline $\mathrm{S} 11$ & 1.88 & 9.80 & 38.56 & 14.77 & 2.08 & 3.89 \\
\hline $\mathrm{S} 12$ & 19.62 & 5.45 & 5.86 & 18.99 & 2.26 & 3.24 \\
\hline Dutch standard ${ }^{\mathrm{a}}$ & 100 & 35 & 36 & 29 & 0.80 & 85 \\
\hline Canadian guidelines $^{b}$ & 64 & 50 & 63 & 12 & 1.4 & 70 \\
\hline Australian guidelines $^{c}$ & 50 & 60 & 60 & 20 & 3.0 & 300 \\
\hline
\end{tabular}

aVROM (2000); ' ${ }^{\mathrm{C} C C M E}$ (2003); 'DEP (2003)

Table 2: Metal concentration $(\mathrm{mg} / \mathrm{kg})$ in soil collected from Tangail district brick manufacturing area, Bangladesh.

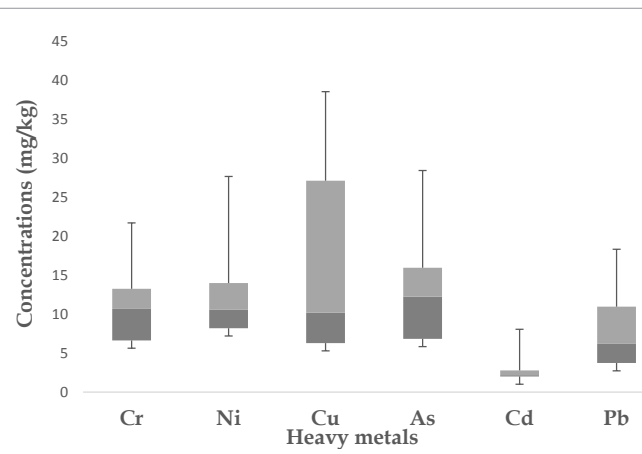

Figure 2: Box-Whisker Graphics Show the distribution of Heavy metals in soils $(\mathrm{mg} / \mathrm{kg})$ collected from Brick kiln area of Tangail district, Bangladesh.

$$
\mathrm{PLI}=(\mathrm{CF} 1 \times \mathrm{CF} 2 \times \mathrm{CF} 3 \times \ldots \times \mathrm{CFn})^{1 / \mathrm{n}}
$$

The overall toxicity status of heavy metals in soils may be assessed from Pollution load index (PLI) calculation. PLI is the share of conclusion of six heavy metals.

\section{Statistical analysis}

The data were statistically analysed using the statistical package, SPSS 20.0 (SPSS, USA). The means of the hazardous element concentrations in soils were calculated. Multivariate methods in terms of principal component analysis (PCA) were used to interpret the potential sources of hazardous element in soil. Other calculations were performed by Microsoft Excel 2010.

\section{Results and Discussion}

\section{Physicochemical Properties and Metals in Soil}

The physicochemical properties of soil are presented in Table 1. The studied soils were slightly acidic to neutral excluding the S11 site that was alkaline (Table 1) because of decomposition of organic matter and subsequent formation of carbonic acid [27]. Electrical conductivity (EC) value of the soil was non saline (0-2 dS/m; SRDI soil salinity class) for all sampling sites which mean the salinity effect is negligible on crop plants. Organic carbon (\%C) ranging 0.551-3.65 where the highest value was observed in soil collected from the S5 site. The textural class of the soil were loam, sandy loam and silt loam (Table 1) according to the United States soil texture classification. The concentrations of heavy metals were measured to estimate the Contamination Factor (Figure 5) and enrichment factors with pollution load index of soil. Mean concentrations of $\mathrm{Cr}, \mathrm{Ni}, \mathrm{Cu}, \mathrm{As}, \mathrm{Cd}$, and $\mathrm{Pb}$ in soil were 10.41 , $12.69,15.66,12.15,3.1$, and $7.98 \mathrm{mg} / \mathrm{kg}$, respectively (Table 2 and Figure 2) found around brick kiln area of Tangail district, Bangladesh. Metals in soils were compared with the other studies in Bangladesh and other countries. Arsenic and cadmium concentrations of the present study were higher than those of the study conducted in Bangladesh, India, Spain, and Turkey (Table 3), pointing out that soils were contaminated by As and $\mathrm{Cd}$. The mean concentrations of As was above 
Citation: Proshad R, Ahmed S, Rahman M, Kumar T (2017) Apportionment of Hazardous Elements in Agricultural Soils Around the Vicinity of Brick Kiln in Bangladesh. J Environ Anal Toxicol 7: 439. doi: 10.4172/2161-0525.1000439

Page 4 of 6

\begin{tabular}{|c|c|c|c|c|c|c|c|}
\hline District (Country) & $\mathrm{Cr}$ & $\mathrm{Ni}$ & $\mathrm{Cu}$ & As & Cd & $\mathrm{Pb}$ & References \\
\hline Tangail, Bangladesh & 10.41 & 12.69 & 15.66 & 12.15 & 3.1 & 7.98 & Present study \\
\hline Bogra (Bangladesh) & 41 & 45 & 42 & 10 & 4.2 & 44 & Islam et al. 2014 \\
\hline Maharashtra (India) & 164 & 171 & 155 & 2.8 & 30 & 42 & Bhagure and Mirgane (2011) \\
\hline Murcia (Spain) & 18 & 14 & 11 & NA & 0.22 & 49 & Acosta et al. (2011) \\
\hline Kayseri (Turkey) & 29 & 45 & 37 & NA & 2.5 & 75 & Tokalıoğlu and. Kartal (2006) \\
\hline Dutch soil quality standard (Target Value) & 100 & 35 & 36 & 29 & 0.8 & 85 & VROM $(2000)$ \\
\hline Dutch soil quality standard (Intervention Value) & 380 & 210 & 190 & 55 & 12 & 530 & VROM (2000) \\
\hline Canadian Environmental Quality Guidelines & 64 & 50 & 63 & 12 & 1.4 & 70 & CCME (2003) \\
\hline Department of Environmental Protection, Australia & 50 & 60 & 60 & 20 & 3 & 300 & DEP (2003) \\
\hline
\end{tabular}

Table 3: Comparison of metal concentration $(\mathrm{mg} / \mathrm{kg})$ in soil of present study with other study and guideline values.

\begin{tabular}{|c|c|c|c|c|c|c|c|c|c|}
\hline \multicolumn{4}{|c|}{ Initial Eigenvalues } & \multicolumn{3}{|c|}{ Extraction Sums of Squared Loadings } & \multicolumn{3}{|c|}{ Rotation Sums of Squared Loadings } \\
\hline Component & Total & $\%$ of variance & Cumulative \% & Total & $\%$ of variance & Cumulative \% & Total & $\%$ of variance & Cumulative \% \\
\hline 1 & 2.154 & 35.9 & 35.9 & 2.15 & 35.9 & 35.9 & 1.82 & 30.45 & 30.45 \\
\hline 2 & 1.485 & 24.74 & 60.64 & 1.48 & 24.74 & 60.64 & 1.72 & 28.78 & 59.23 \\
\hline 3 & 1.169 & 19.48 & 80.12 & 1.16 & 19.48 & 80.14 & 1.25 & 20.88 & 80.12 \\
\hline 4 & 0.739 & 12.31 & 92.43 & & & & & & \\
\hline 5 & 0.266 & 4.42 & 96.86 & & & & & & \\
\hline 6 & 0.188 & 3.13 & 100 & & & & & & \\
\hline \multirow[t]{2}{*}{ Elements } & \multicolumn{3}{|c|}{ Component matrix } & & \multicolumn{5}{|c|}{ Rotated Component Matrix } \\
\hline & PC1 & PC2 & PC3 & & PC1 & PC2 & & PC3 & \\
\hline \multicolumn{2}{|c|}{ Component matrix } & & & & 0.73 & & & & \\
\hline $\mathrm{Cr}$ & 0.55 & -0.52 & & & -0.91 & & & & \\
\hline $\mathrm{Ni}$ & -0.70 & 0.38 & -0.45 & & & & & 0.97 & \\
\hline $\mathrm{Cu}$ & & 0.43 & 0.85 & & 0.64 & & & & \\
\hline As & 0.89 & & & & & 0.64 & & & \\
\hline $\mathrm{Cd}$ & 0.65 & 0.45 & -0.450 & & & 0.87 & & & \\
\hline $\mathrm{Pb}$ & & 0.81 & & & & 0.73 & & 0.40 & \\
\hline
\end{tabular}

Table 4: Total variance explained and component matrices for the hazardous elements in surface soils collected from Tangail district, Bangladesh Extraction Method: principal component analysis.

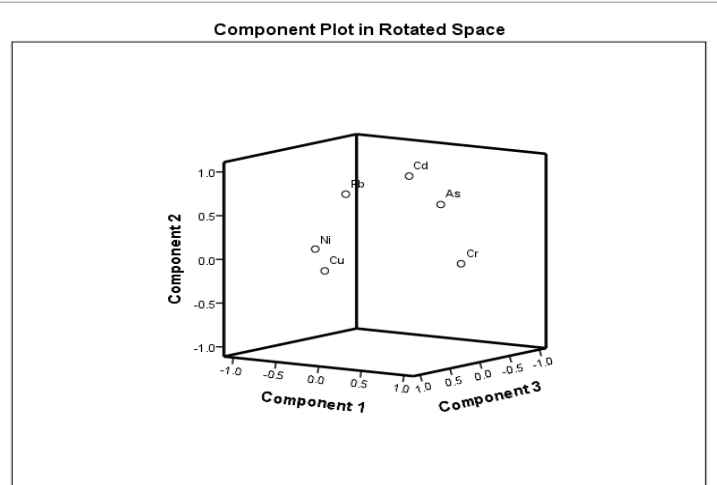

Figure 3: Principle component analysis (PCA) of heavy metals in soils of brick kiln area of Tangail district, Bangladesh.

the Canadian guideline and $\mathrm{Cd}$ in the present study were above the Dutch soil quality standard [28], Canadian guideline and Australian guideline (Table 2). The contaminations of these agricultural fields' soils are a major concern because foods are still being grown on these soils. The Dutch soil quality standard is regarded as the most suitable guideline indicating all possible exposure pathways for protecting humans, plants, and animals. If any metal concentration in soil is below its respective Dutch Target Value, the soil is considered clean. If the concentration level lies between the target values and intervention values, the soil is regarded to be slightly to moderately contaminated. In contrast, if the value is above the Dutch Intervention Value, the soil is considered detrimental to humans, plants, and animals. According to Table 2, Cd was in the worst situation among the studied metals as the mean concentration of $\mathrm{Cd}$ was more than 4 times higher than the Dutch Target value.

\section{Source analysis of hazardous elements in soil}

Principal component analysis (PCA) was carried out to associate the source of heavy metals in soils of several sampling site of the Tangail district, Bangladesh. PCA is assumed ideal act for identification of sources $[29,30]$. Due to source analysis of hazardous element, there

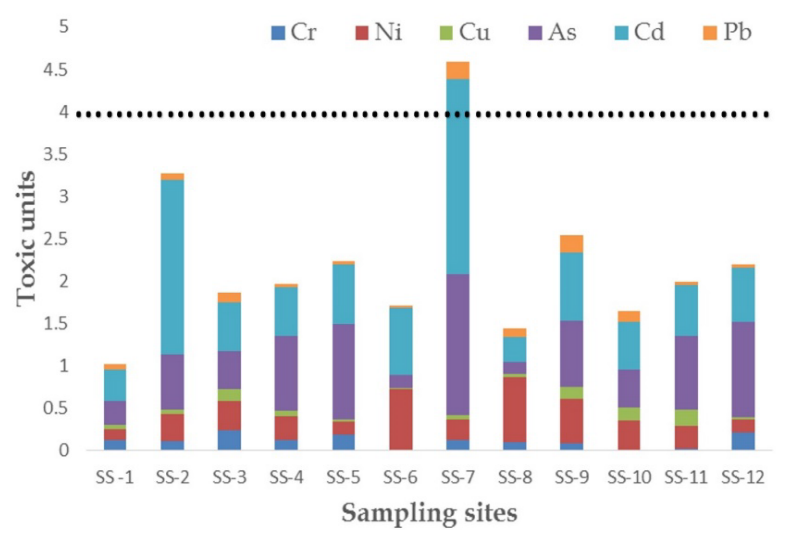

Figure 4: Estimated sum of the toxic unit in soils of brick kiln area of Tangail district, Bangladesh. 
Citation: Proshad R, Ahmed S, Rahman M, Kumar T (2017) Apportionment of Hazardous Elements in Agricultural Soils Around the Vicinity of Brick Kiln in Bangladesh. J Environ Anal Toxicol 7: 439. doi: 10.4172/2161-0525.1000439

prevalent three principal components (Table 4 and Figure 3). Total variation was computed for $80.12 \%$ of source analysis. First principal component (PC1) comprised $\mathrm{Cr}$, As and Cd describing the largest variance (35.9\%); $\mathrm{Ni}$ and $\mathrm{Cu}$ comprised second principal component (PC2) which expound $24.74 \%$ of the variance. Only $\mathrm{Pb}$ comprised third principal component (PC3), describing $19.48 \%$ of the total variance

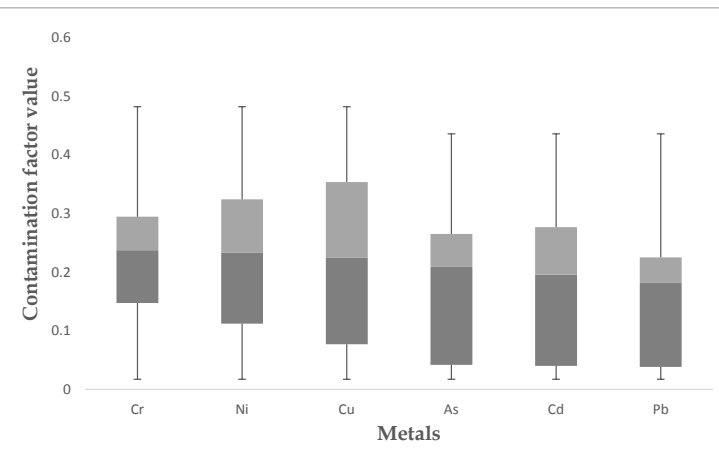

Figure 5: Contamination Factor (CF) of Heavy metals in soils of Brick kiln area of Tangail district, Bangladesh.
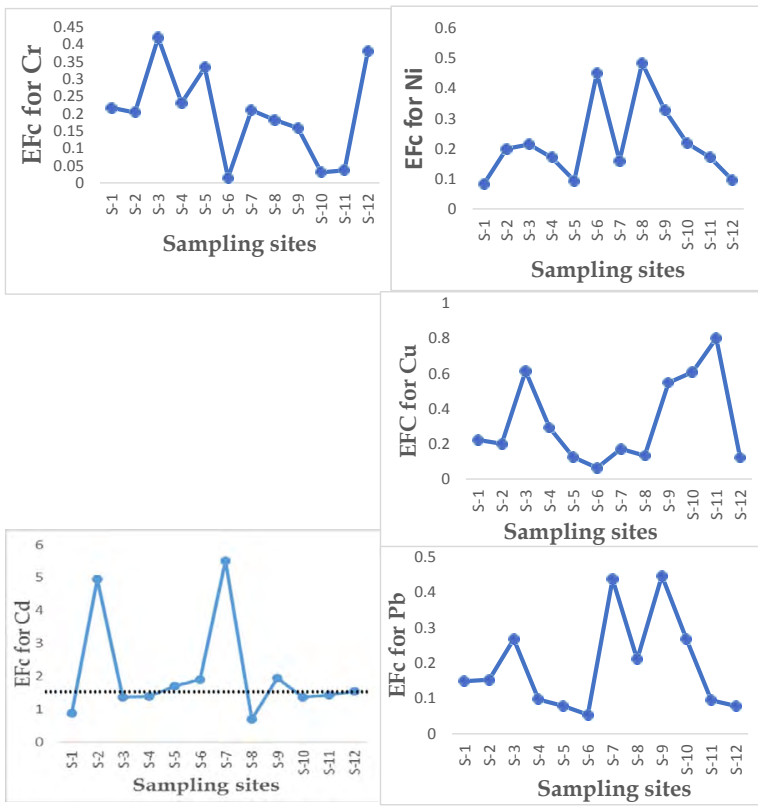

Figure 6: Enrichment factor (EF) values for heavy metals in soils of sampling sites in Tangail district. The horizontal dot lines represent EF value of 1.5.

\begin{tabular}{|c|c|c|c|c|c|c|c|c|}
\hline & $\mathbf{p H}$ & $\mathbf{E C}$ & $\begin{array}{c}\text { Organic } \\
\text { carbon }\end{array}$ & $\mathbf{C r}$ & $\mathbf{N i}$ & $\mathbf{C u}$ & $\mathbf{A s}$ & $\mathbf{C d}$ \\
\hline $\mathbf{E C}$ & $0.604^{*}$ & 1 & & & & & & \\
\hline $\begin{array}{c}\text { Organic } \\
\text { carbon }\end{array}$ & -0.320 & 0.021 & 1 & & & & & \\
\hline $\mathbf{C r}$ & -0.148 & -0.419 & 0.347 & 1 & & & & \\
\hline $\mathbf{N i}$ & 0.081 & -0.081 & -0.383 & -0.459 & 1 & & & \\
\hline $\mathbf{C u}$ & $0.652^{*}$ & 0.361 & -0.052 & -0.243 & -0.094 & 1 & & \\
\hline $\mathbf{A s}$ & -0.209 & -0.335 & -0.272 & 0.312 & $-0.576^{*}$ & -0.060 & 1 & \\
\hline $\mathbf{C d}$ & -0.291 & -0.341 & -0.295 & -0.003 & -0.149 & -0.235 & 0.564 & 1 \\
\hline $\mathbf{P b}$ & -0.106 & -0.264 & -0.177 & -0.011 & 0.149 & 0.287 & 0.261 & 0.382 \\
\hline
\end{tabular}

* $=$ Correlation is significant at the 0.05 level (two-tailed)

${ }^{* *}=$ Correlation is significant at the 0.01 level (two-tailed)

Table 5: Correlation coefficient matrix for physiochemical properties of soil and heavy metals collected from Tangail district brick manufacturing area, Bangladesh.

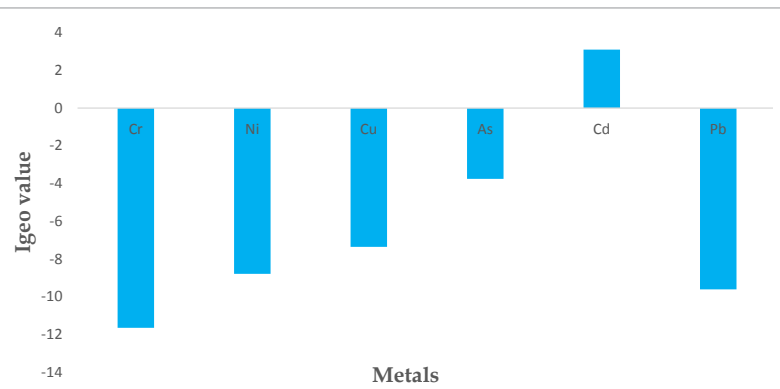

Figure 7: Geo accumulation index $(I)$ value of heavy metals in soils of brick kiln area of Tangail district, Bangladesh.

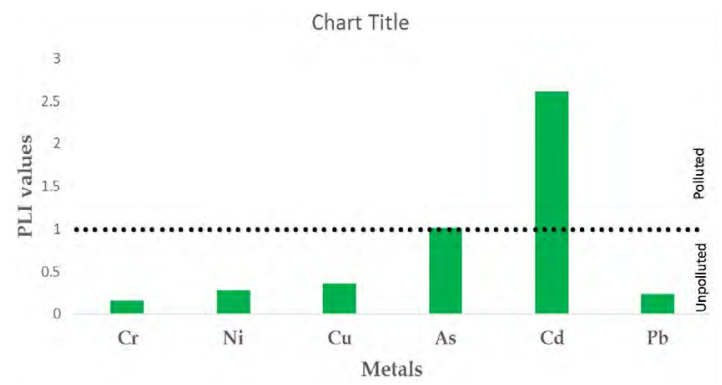

Figure 8: Pollution load index (PLI) value of heavy metals in soils of brick kiln area of Tangail district, Bangladesh.

(Figure 3 and Table 4).

\section{Toxic unit analysis}

Aggregation of Toxic units ( $\Sigma$ TUs) can comprise potential acute toxicity of heavy metals. Toxic units may be defined as the ratio of the determined concentration of metal in soil to probable effect levels (PELs) [30,31]. Toxic unit (TU) and sum of toxic units ( $\Sigma T U s)$ for heavy metals in different soil sampling sites were shown in Figure 4. If the sum of toxic units of soils was more than 4, toxicity of heavy metals is moderate to serious [32]. In the present study, sum of toxic units ( $\Sigma$ TUs) for the sampling sites SS-7 was higher than 4 as well as the other sites, which indicate serious toxicity of heavy metals.

\section{Metal pollution determination in soils}

The EF values of several soils are given in Figure 6 and Table 5 . Average EF values of metals in the present study indicate enrichments in soils of various sampling sites in Tangail district, Bangladesh. As and Cd showed the highest EF value indicate the soil pollution for all the sampling sites.

$I_{\text {geo }}$ values of present study were presented in Figure 7. For all heavy metals, the $I_{\text {geo }}$ values indicated the decreasing order of $\mathrm{Cd}>\mathrm{As}>\mathrm{Cu}>\mathrm{Ni}>\mathrm{Pb}>\mathrm{Cr}$. The mean of $\mathrm{I}_{\text {geo }}$ values for $\mathrm{Cd}$ was 3.104 indicating the soils were heavily contaminated with $\mathrm{Cd}$.

Pollution load index (PLI) value is zero means perfection. If PLI value is equal to 1 , it indicates the pollutants are in background level and PLI values more than 1 comprise the soil is in progressive deterioration contamination of heavy metals $[31,33]$. The pollution state is proportional to numerical PLI value. As per above mentioned value, studied soils were contaminated by $\mathrm{Cd}$ and it was noticed that PLI values of all sampling sites were more than one (Figure 8).

\section{Conclusions}


Citation: Proshad R, Ahmed S, Rahman M, Kumar T (2017) Apportionment of Hazardous Elements in Agricultural Soils Around the Vicinity of Brick Kiln in Bangladesh. J Environ Anal Toxicol 7: 439. doi: 10.4172/2161-0525.1000439

Page 6 of 6

This study presented that soils of all sampling sites were severely contaminated by heavy metals like As and Cd (around $80 \%$ samples crossed the Dutch soil quality target value). The study also assured that concentrations of heavy metal in brick kiln area soils of Bangladesh were varied with different sampling sites. The heavy metals enrichment in soil is also cause of anthropogenic and geogenic elements. As and Cd had very Severe ecological risk for most of the sites for individual heavy metals and the study area comprises ecological risk indexes of these heavy metals were too high. However, it is necessary to conduct further study for describing the causes for the higher potential ecological risk caused primarily by As and $\mathrm{Cd}$ in several sampling sites around brick kiln area in Bangladesh.

\section{Acknowledgment}

The authors thank the authority of Patuakhali Science and Technology University (PSTU), Bangladesh and Yokohama National University, Japan for providing laboratory facilities to complete this study. The authors also delighted to express their gratefulness and sincerest thanks to Dr. Md. Saiful Islam, Associate Professor, Department of Soil Science Patuakhali Science and Technology University, for his valuable suggestions and cooperation to carry out this research.

\section{References}

1. Luo W, Lu Y, Giesy JP, Wang T, Shi Y, et al. (2007) Effects of land use on concentrations of metals in surface soils and ecological risk around Guanting Reservoir, China. Environ Geochem Health 29: 459-471.

2. Islam MS, Shuping HA, AHMED MK, Masunaga S (2014) Assessment of trace metal contamination in water and sediment of some rivers in Bangladesh. $J$ Water Environ Technol 12: 109-121.

3. Lei M, Zhang $Y$, Khan S, Qin PF, Liao BH (2010) Pollution, fractionation and mobility of $\mathrm{Pb}, \mathrm{Cd}, \mathrm{Cu}$, and $\mathrm{Zn}$ in garden and paddy soils from a $\mathrm{Pb} / \mathrm{Zn}$ mining area. Environ Monitor Asses 168: 215-222.

4. UNDP official blog. New York (2011) Bangladesh.

5. Wei B, Yang L (2010) A review of heavy metal contaminations in urban soils, urban road dusts and agricultural soils from China. Microchem J 94: 99-107.

6. Khan MHR, Rahman MK, Rouf AJMA, Oki Y, Adachi T (2006) Evaluation of degradation of agicultural soils associated with brick burning in selected soil profiles in the eastern region of Bangladesh. Jap J Trop Agri 50: 15-30.

7. Yu J, Huang Z, Chen T, Qin D, Zeng X et al. (2012) Evaluation of ecologica risk and source of heavy metals in vegetable-growing soils in Fujian province, China. Environ Earth Sci 65: 29-37.

8. Yuan GL, Sun TH, Han P, Li J, Lang XX (2014) Source identification and ecological risk assessment of heavy metals in topsoil using environmental geochemical mapping: typical urban renewal area in Beijing. China J Geochem Explor 136: 40-67.

9. Liu G, Yu Y, Hou J, Xue W, Liu X, et al. (2014) An ecological risk assessment of heavy metal pollution of the agricultural ecosystem near a lead-acid battery factory. Ecol Indic 47: 210-218

10. Dias CL, Oliveira ML, Hower JC, Taffarel SR, Kautzmann RM, et al. (2014) Nano-minerals and ultrafine particles from coal fires from Santa Catarina, South Brazil. Int J Coal Geol 122: 50-60.

11. Hower JC, O'Keefe JM, Henke KR, Wagner NJ, Copley G, et al. (2013) Gaseous emissions and sublimates from the Truman Shepherd coal fire, Floyd County, Kentucky: a re-investigation following attempted mitigation of the fire. Int J Coal Geol 116: 63-74.

12. Islam MS, Ahmed MK, Habibullah-Al-Mamun M (2015) Metal speciation in soi and health risk due to vegetables consumption in Bangladesh. Environ Monit Assess 187: 288-303.

13. Sikder AH, Molla MD, Hossain MF, Parveen Z (2015) Lead and cadmium accumulation in nearby brick kiln agri-environmental ecosystems. Bangladesh J Sci Res 28: 51-59.
14. Ravankhah N, Mirzaei R, Masoum S (2016) Determination of heavy metals in surface soils around the brick kilns in an arid region, Iran .Geochem. Explor.

15. Islam MS, Ahmed MK, Raknuzzaman M, Habibullah-Al-Mamun M, Islam MK (2015) Heavy metal pollution in surface water and sediment: a preliminary assessment of an urban river in a developing country. Ecol Indic 48: 282-291.

16. Luo W, Lu Y, Giesy JP, Wang T, Shi Y, et al. (2007) Effects of land use on concentrations of metals in surface soils and ecological risk around Guanting Reservoir, China. Environ Geochem Health 29: 459-471.

17. Rashed MN (2010) Monitoring of contaminated toxic and heavy metals, from mine tailings through age accumulation, in soil and some wild plants at Southeast Egypt. J Hazard Mater 178: 739-746.

18. Franco-Uría A, López-Mateo C, Roca E, Fernández-Marcos ML (2009) Source identification of heavy metals in pasture land by multivariate analysis in NW Spain. J Hazard Mater 165: 1008-1015.

19. Selvaraj K, Mohan VR, Szefer P (2004) Evaluation of metal contamination in coastal sediments of the Bay of Bengal, India: geochemical and statistical approaches. Mar Pollut Bull 49: 174-185.

20. Zhang J, Liu CL (2002) Riverine composition and estuarine geochemistry of particulate metals in China-weathering features, anthropogenic impact and chemical fluxes. Estuar. Coastal Shelf Sci 54: 1051-1070.

21. Birch GF, Olmos MA (2008) Sediment-bound heavy metals as indicators of human influence and biological risk in coastal water bodies. J Mar Sci 65: 14071413.

22. Bermejo JS, Beltrán R, Ariza JG (2003) Spatial variations of heavy metals contamination in sediments from Odiel River (Southwest Spain). Environ In 29: 69-77.

23. Rudnick RL, Gao S (2003) Composition of the continental crust. In: Holland H.D., Turekian KK, Treatise on Geochemistry. Elsevier, Amsterdam, Netherlands 3: 1-64

24. Yu GB, Liu Y, Yu S, Wu SC, Leung AO, et al. (2011) Inconsistency and comprehensiveness of risk assessments for heavy metals in urban surface sediments. Chemosphere 85: 1080-1087.

25. Suresh G, Ramasamy V, Meenakshisundaram V, Venkatachalapathy $R$ Ponnusamy V (2011) Influence of mineralogical and heavy metal composition on natural radionuclide concentrations in the river sediments. Appl Radiat Isot 69: $1466-1474$

26. Ahmad S, Siddiqui EN, Khalid S (1996) Studies on certain physic chemica properties of soil of two fresh water ponds of Darbhanga. Environ Pollut 31 31-39.

27. VROM (Volkshuisvesting, Ruimtelijke Ordeningen Milieubeheer) (2000) Circular on Target Values and Intervention Values for Soil Remediation. Spatial Planning and Environment, Netherlands, Ministry of Housing, Spatial Planning and Environment.

28. Bai J, Xiao R, Cui B, Zhang K, Wang Q, et al. (2011) Assessment of heavy metal pollution in wetland soils from the young and old reclaimed regions in the Pearl River Estuary, South China. Environ Pollut 159: 817-824.

29. Anju M, Banerjee DK (2012) Multivariate statistical analysis of heavy metals in soils of a Pb-Zn mining area, India. Environ Monit Assess 184: 4191-4206.

30. Zheng NA, Wang Q, Liang Z, Zheng D (2008) Characterization of heavy meta concentrations in the sediments of three freshwater rivers in Huludao City, Northeast China. Environ Pollut 154: 135-142.

31. Islam MS, Ahmed MK, Habibullah-Al-Mamun M, Hoque MF (2014) Preliminary assessment of heavy metal contamination in surface sediments from a river in Bangladesh. Environ Earth Sci 73:1837-48.

32. Bai J, Xiao R, Cui B, Zhang K, Wang Q, et al. (2011) Assessment of heavy metal pollution in wetland soils from the young and old reclaimed regions in the Pearl River Estuary, South China. Environ Pollut 159: 817-824.

33. Rashed MN (2010) Monitoring of contaminated toxic and heavy metals from mine tailings through age accumulation, in soil and some wild plants at Southeast Egypt. J Hazard Mater 178: 739-746. 